\title{
The Comparative Analysis of the Alternative Crisis Management Models of the Islamic- and Christian-Based Bank System
}

\author{
Dr. Balazs Cseh (Kaposvar University, Hungary) \\ Dr. Jozsef Varga (Kaposvar University, Hungary)
}

\begin{abstract}
There is an increasing demand for investments based on religious basics since these ethical investments mean much more stable financial chances. The economic and financial risk of a fragmented reserve banking system has become obvious by the failure of the neoliberal market economy. Therefore, world economy has to reform the entire credit and bank system that could only be achieved by alternative methods. The Islamic bank is a particularly young alternative opportunity that is based on more equitable and moral principles. However, bringing back the Christian-based banking system that looks back on old traditions and that became extinct could also be an alternative. One of the major principles of the Christian-based banking system is that it is not allowed to borrow and invest in worthless bonds without provision. For the Islamic bank, for instance, speculative affairs that are of high risk and monetary derivates are forbidden, there is voluntary risk management. Risk management and risksharing practices based on alternative religious principles will also be analyzed. Due to its procyclic-anticyclic characteristics, the traditional bank system deepens the crisis while the religious bank systems are against the crisis by alleviating the burdens of the debtor. The authors describe and analyze crisis management solutions with a sort of comparative method.
\end{abstract}

\section{Introduction}

Recent events, the rapid economic changes, the needs from the banking system and the endeavour of approaching to the banking system of the European Union required the new regulation of the activities of credit institutions. Financial services, financial institutions and their scope of activities are determined by national law in Christian tradition. In Islam, as opposed to this, fiqh al-Muamaat means everything that gives a framework for or leads Islamic economic and market conducts in civil environment. It takes care of, on the one hand, economic transactions and on the other hand, of such factors that could influence economic conduct since it also deals with economic relations existing on the Islamic financial market, especially with ba'i, ijarah, istisna'a, salam, murabaha, mudaraba economic bank transactions. Fiqh as rules and definitions of understanding occurs in result-oriented relationship of humans and financial law. During this, the relations of human behaviour and economic operators can be recognized. The relevance of the topic is given by the crisis affecting the traditional banking system and the need for a solution responsing as an alternative to the challenges of sustainable economic growth.

\section{Christian and Islamic Bank Models and Structures}

\subsection{The Prudential Operation of Christian Banking System}

The classification of financial institutions is done by national law of Christian countries on the basis of the activities mentioned previously. Generally, a financial institution can be a credit institution or a financial undertaking. The financia institution besides financial services can only provide additonal financial services, insurance brokerage, commodity brokerage, gold trade transactions and stock bookkeeping. A financial undertaking can provide one or more financial services but it cannot provide additional financial services. In the interbank market, however, financial brokerage can only be provided by financial undertakings as exclusive service.

The global financial crisis beginning in 2008 affected the bank system of the world. The total assets of banks decreased significantly in more east-central European countries so in Hungary, too (Bozsik, 2015). The crisis certainly affected Islamic banks as well, nonetheless Islamic financial activity increased all over the world. Islamic banks due to the strict Saria regulation are more stable and more conventional in the world. The big growth rate of Islamic financing can be thanked to these stability-oriented religious-legal regulations. In 2014 the market of Islamic financial products can be estimated to 2000 billion USD. The division of Islamic financing met the expectations, its $78 \%$ were Islamic bank investments, the more and more popular Sukuk securities showed $16 \%$ share, Takaful 1\%, the Islamic funds 4\% and the Islamic microfinancing also 1\% (Tabash and Dhankar, 2014).

The key of prudential bank operation is the capital adequacy of credit institutions. Capital requirement is of three risk capital requirements: credit risk, operational risk and market risk.

Credit risk is the risk of insufficient (re)paying of loan and interest. Operational risk is the risk of banking processes, the wrong or insufficient operation of humans or systems or the risk of loss deriving from external events that refers to the following major factors:

- internal or external fraud 
- violation of occupational safety regulations

- unintentional loss in customer relations

- damages in physical assets

- business disruption, system failure

- implementation and process management errors

Market risk is the risk of re-pricing of certain items. It can be divided into interest rate, currency and price risks. It is treated together with credit risk.

\subsection{Forbidden Affairs According to Islam during the Prudential Operation of Bank System}

According to Al-Jassas's definition riba is the credit amount to be paid given to a determined period and increased by a determined value, so the interest of the loan and the exchange of such assets that have no appropriate balance value. Consequently, it seems that there are two dimensions of the ban of riba. On the one hand, riba duyun that derives from debt and, on the other hand, riba buyu that is based on the exchange of unequal items so on barter affairs. The so-called ribawi items such as gold, silver, wheat, date and salts representing money belong to here that could be the subject of transactions.

The next ban is gharar that excludes the risk of Islamic transactions that prevents the unfair damage of participants. For instance, if one of the participants has a damage on the side of quantity or quality during the transaction, the contract is null or can be nullified (Biermeier, 2007). The ban is deduced from an-Nisaa': 29 poem and prophet Muhammad's words. They distinguish little and big gahrar, the little is yasir and the big one is the fanish. The ban of risk appears in connection with fundamental risk, risk management methods, religious risk (ar Ra'd: 11) as well as Takaful.

The third one is the ban of speculation, the maisir, which is, as opposed to gharar (that is accepted in little amount), completely unacceptable according to the al-Maidah:90 poem (Steffens, 2014).

It ought to be noted that an Islamic transaction is only valid if it does not come up against any bans and besides this, existing (mawjud), allowed (halal), valid (sahih) and there is value in it (mutaqwwim). For this reason, the subject of transaction cannot be, for instance, dematerialized securities so it cannot be paid with transfer. Besides this, businesses of particular products (haram) such as alcohol, tobacco, pornographic content, etc. are also forbidden (Ashrati, 2008).

\subsection{The Regulatory Frame-models of Christian Bank System}

Currently, a constant change can be recognized whose basis is given by the regulatory frames called Basel. Basel II. Regulation is better in risk management than Basel 1. because it did not recognize only credit risk. Another big step is that Basel II. makes the use of inner rating systems possible, thus credit institutions can work with their own models instead of dictated, external keys. In Hungary currently Basel II. Regulation is valid but the introduction of Basel III is in progress. The Baselic capital requirement system was elaborated by BIS, Bank for International Settlements. BIS was founded in the framework of the Young-plan accepted in 1930 in the second Haguae International Conference in 1930. Its original task was the organization of war reparations paid by Germany during which Germany intended to repay its debt by the output of Young-loan. BIS started its operation in Basel in 1931. Its governing body is the Council which meets annually with the participation of central banks. In the periods between the meetings of the Council, professional work is led by the Board of Directors that chooses its president among its members.

The role of BIS changed due to the economic crisis of 1929-1933. Currently, its most important task is the coordination of central banks, the ensurance of the flow of information and the elaboration of directives and regulations affecting international bank operation. As for the cooperation of central banks, it had a significant role in the coordination of international foreign exchange policy measures. The most important institutional difference between the BIS, IMF and World Bank is that members of BIS are not governments but central banks. As a result, the strong politicization that can be recognized in the other two organization occurs in BIS indirectly. A credit institution, to sustain solvency and to be able to fulfill requirements, has to have a proper size of solvency capital. An important rule is that the sum of the solvency capital cannot be lower than the sum of registered capital prescribed for the credit institution.

\subsection{The Functional and Supervisory Models of the Islam-type bank system}

The Sharia Council monitors all relevant parties in financial transactions on both an individual and a corporate level to ensure that they are conducted with diligence and honour in accordance with Usul al-Fiqh and Fiqh alMuamalat, and that there is no financial abuse or ethical issues. All harmful behaviour, misconduct, fraud and deceit are forbidden and severely punished by Islam. Ethical and legal requirements and regulations are considered equally important when conducting business. Sharia law is definitive in Islamic financing and a standard in financial transactions and procedures, supervision and monitoring. All parties in the financial sector follow its regulations (fiqh) consistently and diligently when they are shaping their financial strategies. It is a progressive approach which considers adequate income, benefits and profit as the most crucial factors. Therefore Sharia law 
in the Islamic financial sector can be considered as a possible solution for progress as demonstrated by their known current financial stability. On the other hand, the pace of development in economic and financial systems based on religious and moral principles is obviously slower, and it can vary in different countries as local ethics can be different. It is also important to mention that the branch of Islamic financial services is still new, thus rigid, regulation-based economic systems can jeopardize its healthy, potential growth or limit its independence. Yet a Sharia-based financial system can provide a healthy and viable environment as it is humanistic and strongly embedded into society (Sharia monitoring includes macro and micro level analyses and it is not restricted to the monitoring of developmental procedures, but covers all banking and financial practices. As it was previously mentioned, Sharia Councils not only make decisions in controversial cases, but provide guidelines for proper conduct which is even more important as avoiding conflict and focus on the future are parts of the specific perspective of Islam.). For example the Katar model is an Islamic banks operate under independent regulations. Although there is no central governing institution, Awqaf has an important influence on them. Fiqh al-Muamalat, the Islamic commercial practice functions in accordance with the regulations of fatwas and Sharia law, therefore it is a common practice of Islamic financial institutions to establish and oversee Sharia Councils. They are also important for monitoring and they make ex-ante and ex-post Sharia decisions.

Islamic financial structure is based on the principle of distributive justice which is a characteristic of a purely Islamic model. Inequalities in income and profit distribution are prevented by the Islamic financial system with correctional measures as welfare is a primary consideration. As economic growth is an objective, basic needs are addressed as a priority and it is also trying to motivate activity in the economy. Islamic economical ethics does not take ethical risks with supply and demand and also investment and consumption but focuses on the development of human resources (Hassan and Lewis, 2014).

The Islamic financial structure is based on Islamic business ethics, Islamic values and their universal applications which could provide a perspective for the traditional Western financial system, as alternative economic theories also attempt to shift their focus towards an ethical, humanistic economic system (Mat and Ismail, 2014). Ethics is one of the aspects of the evaluation of liberal or conservative socioeconomic behaviours, therefore the conclusions based on the evaluations affect those behaviours (Hársfai, 2009).

\subsection{Credit Risk Management in Traditional Banking Systems Based on the Hungarian Example}

The credit risk of Hungarian credit institutions can be measured with two methods: the standard method and the internal ratings-based method. In the standard method, the credit institution determines the risk of exposure and creates different exposure classes for transactions. The more important exposure classes currently in force differentiate between the exposure of central government and central bank, regional government and local government, credit institution and investment firm, and between businesses and the population.

The weighting of the balance sheet of assets is carried out with a classification of $0-150 \%$ weight $(0,20,35,50$, $100,150 \%$ weight). Here are some examples for the different weighting classes: e.g.: $0 \%$ weight: claims against EU central governments and central banks; 35\% weight: residential properties with mortgage; $50 \%$ weight: not residential properties with mortgage; $100 \%$ weight: exposure covered by a property. $150 \%$ weight is the worst classification.

With items outside of the balance sheet, generally a $100 \%$ weight is used, with the following exceptions:

- $0 \%$ weight: undrawn promissory notes and credit limits (when the original expiration date is a maximum of one year away), stand-by (it can be revoked unconditionally at any given time) credit

- $20 \%$ weight: letter of credit

- $50 \%$ weight: Issued or confirmed letter of credit, assumed warranty for issuing securities, irrevocable stand-by letter of credit.

Another method of credit risk management is the internal ratings-based method (IRB). The basis of this regulation is risk assessment by determining the probability value of non-payment. The probability of default (PD) is the probability of non-payment within one year. The loss given default (LGD) is calculated by dividing the loss deriving from non-payment of a client with the exposure of default (EAD).

This method therefore substitutes the risk weights and rankings of external classification with experiential factors derived from the operation of the credit institution. The internal ratings-based method is viable for larger banks with adequate capacity.

The items above constitute the I. pillar of Basel II. The II. pillar is the supervisory review system. After the credit institution determines its own internal capital requirements, a supervisory evaluation is conducted. The credit institution calculates credit requirements based on the classifications to determine whether the institution complies with regulations, this is how the classification of receivables into risk exposure is executed. The investigations must determine whether the credit institution would be able to handle a sudden capital adequacy crisis (e.g.: a sudden outflow of high amount deposits or a massive non-payment of credit debts).

The III. pillar of Basel II. regulates public disclosure. Public disclosure obligations must be fulfilled at least once a year within 15 days of the approval of the annual report about changes in the financial status of the credit 
institution. Relevant information on management and accounting must be disclosed within 30 days of obtaining knowledge of the information. Irrelevant, protected and confidential information is exempt from public disclosure.

\section{A Comparison of Corporate Leadership Practices of Islamic and Traditional Banks}

It is useful to have a brief discussion on the questions of accountable corporate leadership in the context of Islamic and traditional banks. We believe that this provides a basis for comparison between the two banking systems which demonstrates the advantages of the credit policy based on the doctrines of Islam.

According to András Kecskés, accountable corporate leadership is comprised of all relationships between management, ownership, employees and other individuals of an institution, which are governed by legal, ethical, rational, and effective conduct of a profit-oriented approach that also has social utility; and the rules of which are shaped by laws and the self-regulatory processes of the market and business (Kecskés, 2011). If we project this definition to the Islamic banks, then it is clear that their conduct meets the requirements of social utility and ethical behaviour, however an interesting distinction is that a major part of the regulations are not provided by state laws or self-regulations of specific banks, but the doctrines of Islam.

The question of whose interests should be prioritized by the leadership of an institution is also important to discuss in the context of this topic (Kecskés, 2008). We can separate two circles: members (or shareholders in the case of joint-stock companies) and stakeholders (Kecskés, 2010). They are the individuals that are affected by the operation of the institution (Budai, et. al. 2011). This is an extremely wide circle as it also includes business partners (Kecskés 2010). It is evident from the credit policies of Islamic banks that they put a much bigger emphasis on ethical conduct.

\section{Summary}

The introduction of Basel III. changes several areas of prudent operating practices of the traditional banking system. The system of the countercyclical capital buffer was created to address financial crises, and new liquidity requirements are introduced because of the growing importance of banking liquidity. However the approach of the system does not change: the intense profit-seeking behaviour, the necessity of constant growth in terms of financial results and the greed of bank management suggest that this system will not be able to provide security in the future either. Although in some cases Basel III. regulates the income of bank management, but this does not influence the operational logic of the system significantly.

The Islamic banking system still has a clear advantage in terms of prudent operating practices. I analyzed some of the aspects of the cooperation of the Islamic and the traditional banking system and I reached the conclusion that based on the procyclical-countercyclical nature of the banking system, the traditional banking system deepens the crisis by putting additional pressure on the debtor with more severe changes in classification while the Islamic banking system alleviates some of the pressure of the debtor to improve on the crisis. The countercyclical economic and financial policy is one of the key issues of the traditional banking system and the introduction of Basel III. serves as a strong example for that.

The second important operational area of the Islamic banking system, where experiences are transferable, is the sharing of risk in the relationship between saving parties and borrowers. The Islamic banking system is a good example of how the depositor can take responsibility - at least partly - for the investment, so mutual interests can be established between saving parties, the bank, and borrowers.

Based on economic indicators and bank balance sheets we reached the conclusion that there is growing demand on the European money market for the financial institutions of the Islamic banking system which should be addressed by legislature by restructuring the different legal systems and by the revision and interpretation of specific regulations.

The cooperation and reconcilement of the conventional and Islamic economic systems is a timely and urgent matter on both the Western and global levels, which can be seen from the compromises in laws in several countries, the increased number of banks, and the various financial institutions discussed in this study The cooperation and harmonization of the banking systems on a global level is an alternative, its development and financing is an opportunity for the future, and it requires further research.

\section{References}

- Ashrati, 2008, Islamic Banking. Wetvorstellungen - Finanzprudukte - Potenziale. 1. Auflage. Frankfurt am Main. Frankfurt School Verlag. p. 13.

- Biermeier, 2007. Islamische Investition und Finanzierung. Chancen schariakonformer Bankdienstleistleistungen für konventionelle Finanzinstitutionen, GRIN Verlag, Bochum, p. 11.

- Bozsik, 2015. A közép-kelet-európai országok bankrendszerének mérlegalkalmazkodási folyamata a gazdasági válság kirobbanása után, in Fejlődő jogrendszer és gazdasági környezet a változó társadalomban. International Research Institute 2015 pp. 133-143. 
- Budai - Hanák - Hardi - Kazár - Kecskés, 2011. Felelős vállalatirányítási és etikai szótár/ Glossary of corporate governance and business integrity terms The American Chamber of Commerce in Hungary, Budapest, p. 44.

- Hársfai, 2009. Bevezetés a politikai és társadalmi etikába. Szent István Társulat, Budapest, pp. 22-34.

- Hassan,- Lewis, 2014. Handbook on Islam and Economic life. Cheltenham - Northampton, Edward Elgar Publishing, p. 46.

- Kecskés, 2008. Részvényárak mindenek felett? Érdekszférák a vállalatirányítás jogában, in Emlékkönyv Román László születésének 80. évfordulójára, Pécs, pp. 215-234.

- Kecskés, 2010. The Legal Theory of Stakeholder Protection, in JURA, 2010/1., Pécs, pp. 67-76.

- Kecskés, 2011. Felelős társaságirányítás (corporate governance). HVG-ORAC, Pécs, p. 387

- Mat - Ismail, A Review of Fiqh al-Mua'malat Subjects, in Economics and Related Programs at International Islamic University Malaysia and University of Brunei Darussalam, http://www.kantakji.com/media/6426/op57.pdf

- $\quad$ Steffens, 2014. Islamic Finance, GRIN Verlag, Bochum, p. 7.

- Tabash - Dhankar, 2014. The Impact of Global Financial Crisis on the Stability of Islamic Banks: An Empirical Evidence, in Journal of Islamic Banking and Finance March 2014, Vol. 2, No. 1, pp. 367-388. 